\title{
Parenting in Digital Era: Issues and Challenges in Educating Digital Natives
}

\author{
Mahardika Supratiwi', Laelatus Syifa Sari Agustina², Afia Fitriani ${ }^{3}$ \\ 1 Prodi S-1 Pendidikan Luar Biasa Universitas Sebelas Maret, Surakarta \\ 2 Prodi Psikologi Universitas Sebelas Maret, Surakarta \\ 3 Prodi Psikologi Universitas Sebelas Maret, Surakarta \\ email: *1'mahardika.s@staff.uns.ac.id, ${ }^{2}$ laelatussyifa.sa@ staff.uns.ac.id, \\ 3 afia.fitriani@staff.uns.ac.id
}

(C)2018 -JPT Fakultas Psikologi Universitas Negeri Makassar. Ini adalah artikel dengan

akses terbuka di bawah licenci CC BY-NC-4.0 (https://creativecommons.org/licenses/by-nc/4.0/ ).

\begin{abstract}
ABSTRAK
Perkembangan teknologi dan informasi saat ini membawa perubahan yang besar bagi kehidupan manusia. Apalagi dengan munculnya internet dan media digital (smartphone, tablet, laptop, televisi), individu menjadi sangat mudah dalam mengakses berbagai macam informasi. Tidak hanya orang dewasa, anak-anak, bahkan balita saat ini sudah terpapar media digital. Anak-anak dan remaja yang sejak lahir sudah mengenal media digital ini sering diistilahkan sebagai generasi digital natives (DNs). Generasi DNs ini mendapatkan kemudahan yang ditawarkan oleh perkembangan teknologi tersebut, tetapi ternyata tidak luput dari dampak negatif yang menyertai. Penggunaan gadget yang berlebihan pada anak dapat menjadi pemicu munculnya kecanduan terhadap gadget, kerusakan mata, timbulnya stres, bahkan mengarah pada depresi. Melihat fenomena tersebut, maka diperlukan adanya pendampingan oleh orangtua pada saat anak mengakses media digital. Pengasuhan yang tepat dari orangtua dapat membentengi diri anak ketika mengakses media digital dan internet. Tujuan penulisan artikel ini adalah untuk memaparkan pengasuhan orangtua pada era digital. Berdasarkan studi literatur, didapatkan kajian mengenai tahapan pengasuhan orangtua dalam penggunaan media digital berdasarkan model teori perkembangan dan beberapa strategi yang dapat digunakan orangtua untuk mendampingi anaknya dalam berselancar di dunia maya.
\end{abstract}

Kata kunci: digital natives; pengasuhan; media digital; strategi

\begin{abstract}
The development of technology and information now brings great changes to human life. Especially with the advent of the internet and digital media (smartphones, tablets, laptops, televisions), individuals are very easy to access various kinds of information. Not only adults, children, and even toddlers are now exposed to digital media. Children and adolescents who are born with digital media are often termed as digital generations (DNs). This generation of DNs has the convenience offered by the development of these technologies, but it does not escape the negative effects that accompany them. Excessive use of gadgets in children can be a trigger for the emergence of addiction to gadgets, eye damage, stress, and even lead to depression. Seeing this phenomenon, it is necessary to have assistance by parents when children access digital media. Proper parenting from a parent can fortify a child when accessing digital media and the internet. The purpose of writing this article is to describe parenting in the digital age. Based on a literature study, a study was conducted on the stages of parenting in the use of digital media based on development theory models and some strategies that parents can use to assist their children in surfing in cyberspace.
\end{abstract}

Keywords: digital natives; nurturing; digital media; strategy 


\section{PENDAHULUAN}

Perubahan besar yang mengiringi kemajuan teknologi dan informasi berdampak pada setiap aspek kehidupan. Individu dari semua usia semakin mendapatkan kemudahan dalam mengakses berbagai macam informasi melalui perangkat digital dan internet. Survei yang diselenggarakan oleh Asosiasi Penyelenggara Jasa Internet Indonesia (APJII) pada tahun 2018, menunjukkan bahwa terdapat $64,8 \%$ atau 171,17 juta dari 264,16 juta jiwa populasi penduduk Indonesia merupakan pengguna internet secara aktif (Asosiasi Penyelenggara Jasa Internet Indonesia, 2018). Berdasarkan survei APJII tahun 2018 tersebut, diketahui bahwa sebanyak $25,2 \%$ dari populasi anak usia 5-9 tahun sudah menjadi pengguna internet dan $66,2 \%$ populasi anak usia 10 14 tahun telah mengakses internet. Selanjutnya, populasi remaja usia 15-19 tahun menjadi pengguna internet yang tertinggi (91\%) dibanding semua kategori usia. Data-data tersebut menunjukkan bahwa sebagian besar anak-anak dan hampir seluruh remaja Indonesia telah terkoneksi dengan internet dari perangkat digital (gadget) yang dimiliki. Individuindividu inilah yang disebut sebagai digital natives (Prensky, 2001).

Digital natives (DNs) merupakan generasi yang sejak lahir telah terpapar dengan kecanggihan teknologi dan tidak mengalami kesulitan yang berarti saat mengakses teknologi (Prensky, 2001). Paparan terhadap teknologi sejak lahir ini menyebabkan DNs memiliki kebiasaan dan karakter yang berbeda dengan generasi sebelumnya. Pengetahuan, wawasan, dan pikiran generasi DNs ini sangat terbuka terhadap perkembangan teknologi, mudah menangkap berbagai informasi, dan cepat beradaptasi dalam berbagai situasi (Azizah, Ocktaviane, Susanti, \& Putri, 2017). Bahkan para DNs ini melakukan kegiatan belajarnya juga dengan mengoperasikan gadget yang terkoneksi internet.

Internet dan gadget memang memiliki pengaruh positif jika dapat digunakan dengan baik. Namun, penggunaan internet dan gadget dengan intensitas yang tinggi seringkali malah berdampak negatif. Terlebih jika para DNs ini kurang dapat menyaring informasi-informasi yang diaksesnya, maka dimungkinkan akan terbawa arus negatif dari perkembangan teknologi, khususnya perangkat digital.

Fenomena terkait dampak negatif gadget ini banyak bermunculan, salah satunya adalah rusaknya penglihatan (menjadi juling) seorang anak di Cina karena menggunakan ponsel selama 10 jam tiap hari (Azizah K. N., 2019). Paparan terhadap konten pornografi juga menjadi salah satu dampak negatif gadget yang perlu diperhatikan. Berdasarkan survei yang dilakukan oleh Komisi Perlindungan Anak 
dan Perempuan (KPAI) pada tahun 2014, sebanyak 97\% anak usia sekolah dasar (SD) dan sekolah menengah pertama (SMP) sudah pernah melihat pornografi (Azizah, Ocktaviane, Susanti, \& Putri, 2017). Sumber pornografi tersebut didapatkan dari media sosial, advertisement (Ads.) yang muncul saat membuka aplikasi, game online, Youtube, pencarian di google, dan dari aplikasi yang bermuatan konten dewasa.

Selanjutnya, permasalahan kecanduan video game juga menjadi salah satu dampak negatif dari gadget yang saat ini banyak ditemui pada masyarakat. Tidak hanya anak-anak, namun orang dewasa juga sering dijumpai memainkan game online dalam setiap kesempatan. Padahal menurut World Health Organization (WHO) dalam International Statistical Classification of Diseases and Related Health Problems (ICD-11), kecanduan game ini akan dimasukkan ke dalam kategori gangguan kejiwaan Gaming Disorder (Snider, 2019). Hal tersebut tentu saja perlu menjadi perhatian khusus bagi orangtua. Di sisi lain, orangtua dihadapkan dengan makin meningkatnya kompleksitas dunia digital serta konsekuensi sosial maupun perkembangan dari kompleksitas tersebut. Selanjutnya, ketidaksetaraan dalam mediasi orang tua muncul berdasarkan tingkat pendidikan atau status sosial ekonomi orangtua (Paus-Hasebrink, Bauwens,
Durager, \& Ponte, 2013). Orangtua yang berasal dari tingkat sosial ekonomi atau pendidikan rendah cenderung kurang melek terhadap kemajuan media digital, sehingga anak-anaknya dibiarkan menggunakan media digital sendiri tanpa pendampingan dari orangtua (Mascheroni, Livingstone, Dreier, \& Chaudron, 2016).

Melihat fenomena-fenomena tersebut, perlu adanya pendampingan bagi para generasi DNs ini. Pendampingan tersebut utamanya diberikan oleh keluarga, khususnya orangtua. Sesuai dengan fungsi keluarga dalam pendidikan, keluarga memberikan pendidikan menyangkut penanaman, pembimbingan, atau pembiasaan nilai-nilai agama, budaya, dan keterampilan-keterampilan tertentu yang bermanfaat bagi anak (Yusuf, 2009).

Pemberian media digital dalam keseharian anak dipengaruhi oleh gaya pengasuhan atau etika orangtua (Clark, 2013). Saat ini terdapat istilah digital parenting, yang merujuk pada konsep bagaimana orangtua terlibat penuh dalam meregulasi perilaku anak dalam mengakses media digital (mediasi orangtua atau parental mediation) dan bagaimana orangtua memanfaatkan media digital dalam kehidupan sehari-harinya (Mascheroni, Ponte, \& Jorge, 2018). Orangtua memiliki tanggungjawab penuh dalam menyediakan sumber-sumber informasi dari internet dan melindungi 
mereka dari risiko-risiko akibat penggunaan internet. Selain itu, orangtua perlu memberikan batasan yang jelas pada anak mengenai hal yang diperbolehkan dan tidak diperbolehkan ketika menggunakan perangkat digital. Orangtua juga secara rutin perlu mendiskusikan dengan anak halhal apa saja yang telah dilakukannya saat mengakses internet dan membantu anak ketika menemui kesulitan saat online (Smahel, 2016).

Tujuan penulisan artikel ilmiah ini adalah untuk menguraikan isu, tantangan, dan pentingnya peran pengasuhan orangtua dalam mendidik generasi DNs. Selain itu, dibahas pula mengenai bentuk-bentuk pendampingan orangtua dalam mendidik generasi DNs ini. a. Tahapan pengasuhan orangtua dalam penggunaan media digital berdasarkan model teori perkembangan Model teori perkembangan mensintesis tahapan pengasuhan dalam penggunaan media berdasarkan tahap-tahap perkembangan individu dengan tujuan menjelaskan bagaimana media digital dapat mempengaruhi pengasuhan dan dinamika keluarga sepanjang kehidupan (Dalope \& Woods, 2018). Tahapan pengasuhan tersebut terbagi menjadi lima (Dalope \& Woods, 2018), yaitu nurturing, authority, interpretive, interdependent, dan departure. Berikut disajikan ilustrasi mengenai tahapan pengasuhan orangtua dikaitkan dengan penggunaan media dan dampaknya terhadap dinamika dalam keluarga (Dalope \& Woods, 2018).

\section{DISKUSI}

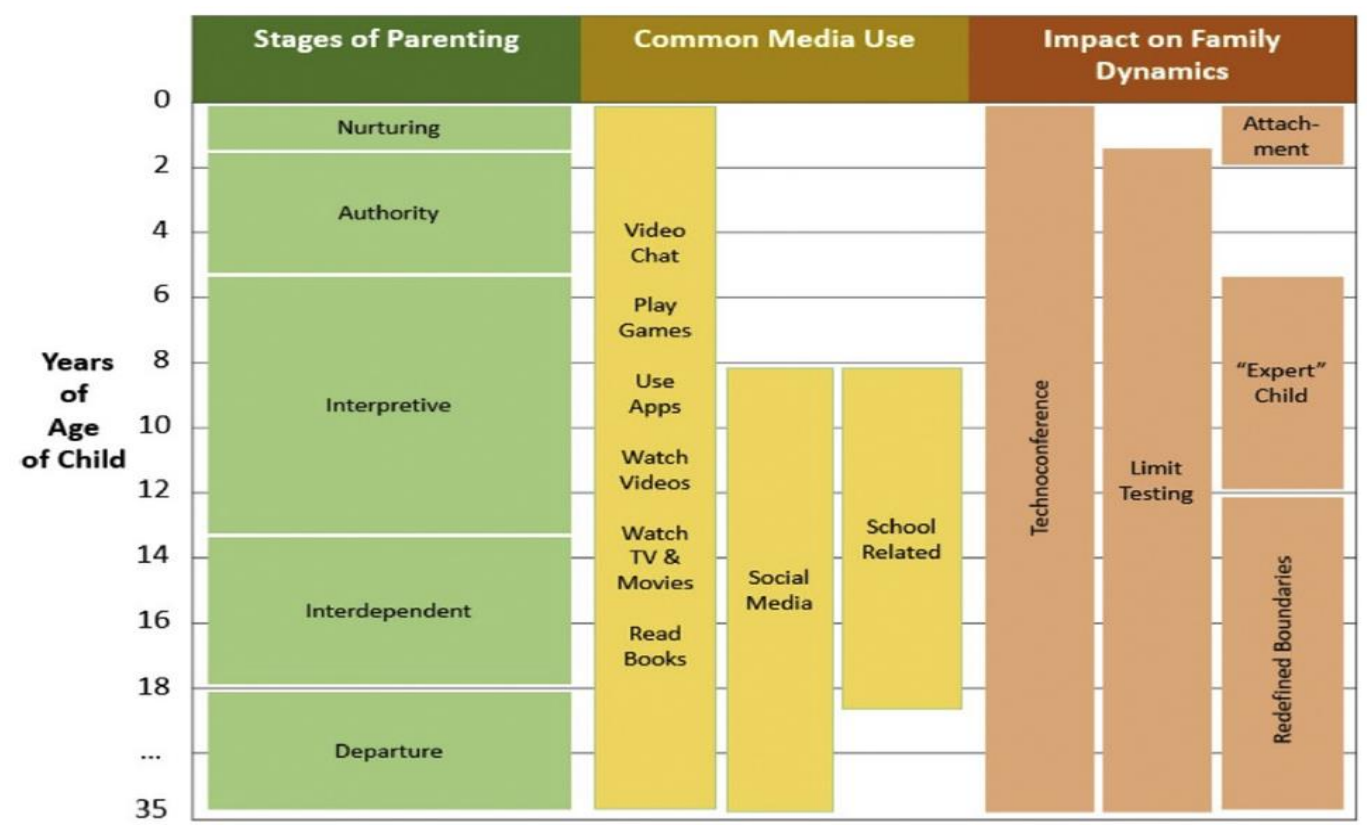

Gambar 1. Tahapan Pengasuhan Orangtua Dikaitkan dengan Penggunaan Media dan Dampaknya pada Keluarga 
1) Nurturing: Tahap bayi dan balita awal ( $0-18$ bulan)

Tahap nurturing ini merupakan masa orangtua untuk mengenali kepribadian anak dan membentuk kelekatan. Ketika media digital dilibatkan dalam masa ini, interaksi antara orangtua-anak akan terganggu. Misalnya orangtua sering melakukan aktivitas online dengan berbagai alasan (rasa bosan, berbelanja, interaksi sosial), maka saat melakukan hal tersebut kemungkinan akan kehilangan mengamati cues dari anak, atau juga akan terlambat dalam menanggapi kebutuhan anak. Jika aktivitas online tersebut sering dilakukan, maka kontak mata dan pembicaraan akan berkurang. Bermain akan menjadi tidak interaktif atau tergeser oleh penggunaan media digital. Orangtua-anak akan menjadi kurang responsif satu sama lain, padahal seharusnya orangtua-anak ini menjadi semakin lekat melalui interaksi-interaksi kecil, terfokus, dan sering. Proses kelekatan tersebut kemudian terdampak secara tidak langsung karena adanya media digital.

Dalam hal interaksi langsung dengan media digital, orangtua biasanya memperbolehkan bayi dan balita untuk melakukan video chat dengan kerabat yang jauh, sehingga dapat meningkatkan kesempatan bertemu dan membangun ikatan antara anak dengan orang lain. Seiring balita makin matang, orangtua kemudian memperbolehkan untuk menggunakan aplikasi-aplikasi pendidikan, membaca e-book, bermain games, dan menonton video, televisi, dan film.

2) Authority: Tahap balita akhir dan anak prasekolah (18 bulan-5 tahun)

Memasuki usia 2 tahun, orangtua memutuskan menjadi figur yang seperti apa. Selanjutnya orangtua akan mengembangkan, menentukan, dan menjalankan aturan-aturan dan batasanbatasan yang jelas. Orangtua kemungkinan memperbolehkan balita memakai media digital, tetapi dengan alasan-alasan tertentu. Beberapa alasan tersebut diantaranya adalah smartphone membantu menjaga anak lebih tenang (Radesky, PeacockChambers, Zuckerman, \& Silverstein, 2016) atau dapat mengalihkan perhatian anak sementara orangtua mengerjakan tugas-tugas lain seperti mencuci, mandi, dan menelpon (Radesky, et al., 2016). Biasanya akan muncul konflik ketika orangtua mencoba mengakhiri penggunaan media, yaitu anak masih ingin menggunakan media tersebut. Cara penyelesaian konflik tersebut selanjutnya bergantung pada temperamen orangtua dan anak, serta gaya pengasuhan orangtuanya.

3) Interpretive: Tahap anak usia sekolah (6-12 tahun)

Orangtua memutuskan nilai-nilai yang perlu diajarkan pada anak, tingkat keterlibatan dengan saudara atau teman sebaya, dan tingkat kemandirian yang perlu 
dimiliki anak. Beberapa orangtua masih percaya bahwa anak yang menggunakan teknologi merupakan hal yang menguntungkan.

Pada tahap ini, kemungkinan akan banyak faktor-faktor eksternal yang mempengaruhi peningkatan eksposur terhadap media digital, seperti sekolah dan teman sebaya. Beberapa sekolah terkadang meminta orangtua dan anak untuk menggunakan teknologi untuk kepentingan pengerjaan tugas. Sehubungan dengan peningkatan peran teman sebaya, terkadang anak juga akan meminta waktu lebih banyak untuk mengakses smartphone dan media sosial sehingga anak-anak dapat tetap terkoneksi dengan teman sebayanya.

Anak-anak terkadang meminta perangkat seluler sendiri karena teman sebayanya memiliki. Selanjutnya orang tua bisa saja memberikan perangkat digital tersebut pada anak, namun orangtua perlu memperhatikan tingkat kematangan anak dalam menggunakan media. Banyak keputusan-keputusan online yang perlu dipertimbangkan ketika anak menggunakan medianya dan tingkat kematangan anak akan mempengaruhi pengambilan keputusannya dalam berselancar di dunia maya. Jika ada ketidaksesuaian antara kematangan dan pengambilan keputusan, maka hal tersebut dapat berimplikasi pada bagaimana anak berinteraksi dengan media digital.
4) Interdependent: Tahap remaja (1218 tahun)

Media sosial mengambil peran yang lebih besar karena adanya lingkungan di dunia maya yang dapat dieksplorasi oleh remaja. Jika orangtua belum menegaskan batasan-batasan yang diperlukan sebelum menggunakan media sosial, maka remaja dapat mempelajari dunia online dan meniru perilaku yang dilihatnya tanpa memahami potensi dampak dan konsekuensi jangka panjang dari perilaku tersebut.

Dalam banyak hal, interaksi keluarga yang umum selama tahap ini (menegosiasikan batas-batas dan peran baru) adalah sama seperti di masa lalu ketika orangtua mencoba memahami teknologi baru (misalnya, musik rock and roll, televisi). Meskipun demikian, interaksi keluarga (pengawasan perilaku remaja secara online maupun offline), besarnya dampak keputusan dan tindakan online ini dapat dilipatgandakan dengan adanya penggunaan media digital.

5) Departure: Tahap dewasa awal (lebih dari 18 tahun)

Media digital dapat berfungsi menghubungkan atau malah mengasingkan individu dewasa awal dengan orangtuanya. Dalam hal hubungan orangtua dan para dewasa awal, negosiasi ini dapat berlangsung karena beberapa orangtua sering menghubungi pemilik kos (saat anak berkuliah) sehingga dapat menghambat 
kemandirian anaknya atau ketika orangtua menjadi teman media sosial anaknya agar tetap terkoneksi setiap saat. Hubungan ini mungkin juga perlu dinegosiasi ulang jika anak pindah kembali ke rumah setelah masa perkuliahan. Keluarga harus memutuskan perilaku apa yang dapat diterima dan sesuai, baik untuk orang tua maupun individu dewasa muda tersebut.

b. Mediasi Orangtua (Parental mediation)

Orangtua merupakan orang yang paling berpengaruh dalam perkembangan dan sosialisasi anak (Sonck, Nikken, \& Haan, 2013), sehingga memiliki tanggungjawab penuh dalam perkembangan yang berkaitan dengan media dan kesejahteraan anak (Shin \& Li, 2017). Strategi-strategi yang dapat dilakukan orangtua untuk melindungi anakanak dari ancaman negatif dari media sekaligus untuk menanamkan perkembangan positif pada anak (Naab, 2018), antara lain:

1) Mediasi aktif (active mediation)

Pada strategi ini, orangtua berpartisipasi aktif dalam menjelaskan dan mendiskusikan suatu media pada anakanaknya (Naab, 2018). Fokus dari strategi ini adalah negosiasi positif, negatif, atau argumen-argumen netral pada orangtua dan anak mengenai penggunaan media. Mediasi aktif ini dapat meningkatkan pemahaman anak terhadap konten media, mendukung perkembangan pemikiran kritis terhadap media, dan mencegah munculnya perilaku agresif yang ditimbulkan oleh media.

2) Mediasi terbatas (restrictive mediation)

Strategi ini mencakup aturan-aturan implisit dan eksplisit dari orangtua yang meregulasi penggunaan media pada anak. Aturanaturan ini biasanya dikaitkan dengan durasi waktu yang diperbolehkan bagi anak mengakses media, apakah konten media tersebut ingin digunakan, atau juga keduanya. Berdasarkan beberapa penelitian, mediasi terbatas ini dapat mengurangi risiko terhadap paparan media, penggunaan media, dan perilaku agresif anak. Meskipun demikian, ada juga penelitian yang menemukan bahwa terdapat dampak negatif yang kontradiktif dengan tujuan akhir dari mediasi orangtua. Mengingat dampak kontradiktif tersebut (Martins, Matthews, \& Ratan, 2015), masih menjadi perdebatan apakah efek dari strategi regulasi ini sebagian besar mencerminkan tingkat kepentingan orangtua sebagai figur otoritas bagi anakanaknya.

3) Penggunaan media bersama (media co-use)

Strategi ini dilakukan melalui adanya pengawasan dan pemantauan orangtua dengan cara penggunaan media bersama (media co-use) pada aktivitas media yang dilakukan anak, bahkan orangtua dapat mengambil tindakan pencegahan jika 
diperlukan. Strategi ini besar hubungannya dengan negosiasi non verbal dalam relasi orangtua-anak. Oleh karena itu, penggunaan media pada anak yang didasarkan pada keinginan orangtua serta penggunaan media bersama menandakan adanya persetujuan dari orangtua tentang konten media yang dapat diakses oleh anak.

Berdasarkan penjelasan dan uraian mengenai pengasuhan pada era digital ini, maka orangtua diharapkan memiliki pengetahuan yang memadai mengenai perkembangan teknologi, khususnya media digital. Selain itu, orangtua perlu memahami permasalahan-permasalahan dan tantangan yang dihadapi ketika anak mengakses internet tanpa adanya pengawasan. Selanjutnya, orangtua dapat memberikan pendampingan dan mediasi secara terus menerus ketika anak terkoneksi dengan internet.

\section{DAFTAR PUSTAKA}

Asosiasi Penyelenggara Jasa Internet Indonesia. (2018). Laporan Survei: Penetrasi \& Profil Perilaku Pengguna Internet Indonesia.

Azizah, K. N. (2019, Agustus 21). Mata Anak Ini Mendadak Juling Akibat Game di Ponsel 10 Jam Tiap Hari. Diambil kembali dari Detik Health: https://health.detik.com/true-story/d4674143/mata-anak-ini-mendadakjuling-akibat-main-game-di-ponsel10-jam-tiaphari?_ga=2.42042787.740297047.15 67747962-1363101587.1560413952

Azizah, L. N., Ocktaviane, N., Susanti, W., \& Putri, P. (2017). Modul Pelatihan
Parenting di Era Digital. Jakarta: Kementrian Pemberdayaan Perempuan dan Perlindungan Anak Republik Indonesia.

Clark, L. (2013). The Parent App: Understanding Families in the Digital Age. Oxford: Oxford University Press.

Dalope, K. A., \& Woods, L. J. (2018). Digital Media Use in Families: Theories and Strategies for Intervention. Child and Adolescent Psychiatric Clinics of North America, 27(2), 145-158.

Martins, N., Matthews, N. L., \& Ratan, R. A. (2015). Playing by the Rules: Parental Mediation of Video Game Play. Journal of Family Issues, 1-24.

Mascheroni, G., Livingstone, S., Dreier, M., \& Chaudron, S. (2016). Learning Versus Play or Learning Through Play? How parents' Imaginaries, Discourses and Practices Around ICTs Shape Children's (digital) Literacy Practices. Media Education, 7(2), 261-280.

Mascheroni, G., Ponte, C., \& Jorge, A. (2018). Digital Parenting: The Challenges for Families in the Digital Age. Boras: The International Clearinghouse on Children, Youth and Media.

Naab, T. (2018). From Media Trusteeship to Parental Mediation: The Parental Development of Parental Mediation. Dalam G. Mascheroni, C. Ponte, \& A. Jorge, Digital Parenting: The Challenges for Families in the Digital Age (hal. 93-102). Göteborg: Nordicom.

Paus-Hasebrink, I., Bauwens, J., Durager, A., \& Ponte, C. (2013). Exploring Types of Parent-Child Relationship and Internet use Across Europe. Journal of Children and Media, 7(1), 114-132.

Prensky, M. (2001). Digital Natives, Digital Immigrants. On the Horizon, 9(5), 16. 
Radesky, J. S., Eisenberg, S., Kistin, C. J., Gross, J., Block, G., Zuckerman, B., \& Silverstein, M. (2016). Overstimulated Consumers or NextGeneration Learners? Parent Tensions About Child Mobile Technology Use. Annals of Family Medicine, 14(6), 503-508. doi:10.1370/afm.1976

Radesky, J. S., Peacock-Chambers, E., Zuckerman, B., \& Silverstein, M. (2016). Use of Mobile Technology to Calm Upset Children: Associations with Social-Emotional Development. JAMA Pediatric, 140(4), 379-399. doi:10.1001/jamapediatrics.2015.426 0

Shin, W., \& Li, B. (2017). Parental mediation of children's digital technology use in Singapore. Journal of Children and Media, 11(1), 1-19. doi:10.1080/17482798.2016.120380 7

Smahel, D. (2016). Digital Parenting: Fathers are crucial for digital security. Brno: Masaryk University.

Snider, M. (2019, Mei 28). Video game addiction is officially considered a mental disorder, WHO says. Diambil kembali dari USA Today: https://www.usatoday.com/story/tech /news/2019/05/28/who-officiallyclassifies-video-game-addictionmental-disorder/1256352001/

Sonck, N., Nikken, P., \& Haan, J. d. (2013). Determinants of Internet Mediation: A comparison of the reports by Dutch parents and children. Journal of Children and Media, 7(1), 96-113. doi:10.1080/17482798.2012.739806

Yusuf, S. (2009). Psikologi Perkembangan Anak dan Remaja. Bandung: PT Remaja Rosdakarya Offset 